\title{
HUBUNGAN ANTARA PENGETAHUAN GIZI DAN MOTIVASI BELAJAR DENGAN KREATIVITAS SISWA DALAM MENGOLAH MAKANAN

\section{Abstrak}

The objective of the research is to study correlation between knowledge of nutrition and learning motivation with student creativity in a food process. The research carried out at Public Senior Vocational School (SMKN) in Jakarta, with 90 respondents selected by using cluster random sampling. The research concludes that there are positive correlation between knowledge of nutrition with student creativity in a food process, with $r_{y 1}=.728$ and $\hat{Y}=91.316+4.499 X_{1}$, and there is a positive correlation between learning motivation with student creativity in a food process, with $r_{y 2}=.863$ and $\hat{Y}=25.021+$ $1.516 X_{2}$. Furthermore, there is a positive correlation between those two independent variables with student creativity in a food process, with $R_{y .12}=.971$ and $=5.354+1.559 X_{1}+1.543 X_{2}$.

\section{PENDAHULUAN}

Pada hakikatnya, manusia memiliki ikatan dengan alam. Hal ini disebabkan alam baik langsung maupun tidak langsung memberikan penghidupan terhadap manusia. Ikatan antara keduanya memberikan pengetahuan tentang bagaimana manusia memperlakukan alam yang menjadi tanggungjawab moralnya.

*) Dra. Sri Kawuryan Hastowati, M.Pd., adalah Dosen Universitas Negeri Jakarta (UNJ). 
Manusia sebagai makhluk sosial (zoon politicoon) yang selalu hidup tergantung pada lingkungan sekitarnya dan juga saling berinteraksi membentuk koloni yang disebut masyarakat daerah. Suatu masyarakat daerah memiliki sistem kependudukan yang merupakan ikatan atau aturan yang disepakati dan menjadi pola aturan warga di dalamnya. Pola dan sistem kehidupan masyarakat yang mendiami wilayah tertentu memiliki karakteristik yang urgen untuk diketahui. Pada daerah yang penduduknya banyak, komunitas, aturan, dan kekerabatan yang dimiliki juga memiliki banyak karakteristik. Hal ini menjadikan banyaknya penafsiran yang dapat dilakukan.

Keragaman pola dan sistem kehidupan masyarakat mengharuskan memiliki pemahaman yang optimal sehingga dapat memanfaatkan lingkungan bagi kelangsungan hidupnya. Adanya pemanfaatan ini menjadikan lingkungan hidup menjadi terpelihara. Lingkungan hidup yang terpelihara akan menjadi lingkungan yang ramah terhadap manusia. Lingkungan hidup yang demikian akan mampu menciptakan situasi dan kondisi serta kesejukan hati bagi manusia yang ada di dalamnya. Kehidupan yang demikian menjadi prasyarat tumbuh kembangnya masyarakat yang sehat, bersih, dinamis, dan mampu beradaptasi dengan alam.

Lingkungan merupakan bagian dari sebuah ekosistem, yang menurut Odum (1997), ekosistem adalah kesatuan unit organisme hidup (biotik) dan substansi-substansi tak hidup (abiotik) yang saling berinteraksi untuk menghasilkan suatu pertukaran materi antara komponenkomponen tersebut. Berkaitan dengan hal ini, banyak aspek kehidupan perlu dikaji sehingga implikasi positif dalam kaitannya dengan pelestarian lingkungan alam akan tetap terjaga. Keadaan demikian menjadikan eksploitasi yang dilakukan manusia terhadap lingkungan alam menjadi berakibat positif. Artinya bahwa selain memanfaatkan lingkungan, manusia juga berusaha memelihara dan melestarikan lingkungan di sekitarnya.

Untuk itu, perlu adanya perhatian dari berbagai pihak, seperti yang dikemukakan Mesarovic dan Pestel bahwa dalam menanamkan sikap 
pembangunan yang bijaksana terhadap lingkungan hendaknya mempertimbangkan faktor-faktor (1) kesadaran tentang bumi sebagai milik bersama, (2) pengembangan etika baru dalam pembangunan sumber daya alam (3) sikap keharmonisan dengan alam, dan (4) manusia harus mengembangkan sikap bertanggungjawab terhadap generasi mendatang (1974).

Banyak negara di berbagai belahan dunia mengalami krisis multidimensi. Beberapa indikatornya adalah masalah bahaya kelaparan dan malgizi (salah gizi). Penyebab kelaparan dan malgizi lebih disebabkan oleh akibat kurang tanggapnya masyarakat dalam memelihara dan memanfaatkan lingkungan secara baik.

Salah satu dampak yang lebih dominan pada empati lingkungan tersebut adalah kurangnya perhatian dalam memanfaatkan pangan dan mengolah makanan secara baik. Kondisi ini dapat mengakibatkan terjadinya rawan kesehatan pangan, timbulnya banyak penyakit, baik dalam bentuk penyakit jenis ringan maupun penyakit yang menyebabkan kematian. Kurangnya pemahaman tentang cara mengelola pangan dan mengolah makanan bergizi akan berdampak pada minusnya pemahanan tentang cara mengkonsumsi dan mengakomodasi pangan yang bergizi. Oleh sebab itu, dalam hal ini diperlukan adanya strategi dan sosialisasi tentang perlunya perhatian menyantap makanan dengan mengkonsumsi makanan bergizi yang dibutuhkan oleh tubuh serta menekankan pentingnya pemahaman gizi.

Pemahaman ini dapat dijadikan sebagai wahana pemenuhan kebutuhan yang mengakomodasikan pengetahuan tentang makanan dan gizi. Pemahaman ini mampu menumbuhkembangkan sehat jasmani, pembentukan fisik yang segar serta pertumbuhan secara proporsional dengan mewujudkan manusia yang memiliki potensi.

Pada saat ini, Indonesia sedang mengalami krisis ekonomi. Dampak yang terjadi mengakibatkan banyaknya keluarga yang mengalami rawan gizi dan tidak berkecukupan untuk makan. Munculnya keluarga miskin berakibat makin meningkatnya jumlah penduduk Indonesia yang 
berada di bawah garis kemiskinan. Kondisi tersebut sangat mempengaruhi tingkat pemenuhan kebutuhan makanan dan gizi yang baik bagi masing-masing keluarga agar dapat memenuhi standar gizi dan terpenuhinya makanan sehat secara higienis.

Semakin kompleksnya permasalahan malgizi bagi masyarakat sehingga memerlukan perbaikan secara mendasar yang menyangkut sektor multidimensi dalam pemenuhan target keseimbangan antara makanan dan masyarakat. Perbaikan bidang makanan dan gizi secara strategis menjadi prioritas menuju perkembangan hidup yang sejahtera.

Salah satu upaya dalam mengatasi permasalahan sebagaimana dijelaskan, adalah melalui pengetahuan tentang gizi dan adanya kemampuan untuk mengolah makanan yang akan dihidangkan. Melalui penguasaan pengetahuan tentang gizi memberikan formulasi komposisi makanan yang bergizi, yakni menyangkut empat zat pokok yang terdiri dari lemak, protein, karbohidrat, dan air.

Formulasi komposisi makanan ini menghasilkan susunan makanan yang seimbang, mempunyai resep, memiliki kandungan gizi yang tinggi, dan variasi pengolahan makanan menjadi pilihan utama untuk mengatasi masyarakat yang kurang gizi. Oleh sebab itu, dalam situasi ekonomi yang sedang dalam krisis multi dimensional diperlukan pemilihan dan prioritas perbaikan standar kesehatan melalui pemilihan makanan yang memiliki kandungan gizi tinggi dengan harga yang terjangkau. Upaya ini dapat dilakukan dengan menumbuhkan kreativitas dalam mengolah makanan dengan bahan-bahan dasar yang terjangkau penduduk.

Kreativitas mengolah makanan dapat diwujudkan dengan memberikan kesempatan kepada penduduk untuk mendalami pengetahuan tentang gizi dan pengolahan makanan. Pendalaman tentang gizi dapat diperoleh penduduk melalui penyuluhan-penyuluhan atau menempuh pendidikan pada sekolah yang mendalami tentang ilmu gizi dan pengolahan makanan. 
Sekolah Menengah Kejuruan (SMK) sebagai salah satu lembaga pendidikan memiliki esensi pengajaran pada keterampilan. Rasional Sekolah Menengah Kejuruan (SMK) ini berorientasi kepada pembentukan keterampilan praktis yang secara langsung dapat diterapkan ke dalam kehidupan sehari-hari. Jurusan tata boga merupakan salah satu jurusan yang terdapat pada Sekolah Menengah Kejuruan (SMK). Esensi pengajaran pada jurusan ini berorientasi pada pengolahan makanan dengan memperhatikan kandungan gizi pada setiap hidangan yang dihasilkan.

Upaya menghasilkan lulusan Sekolah Menengah Kejuruan (SMK) Jurusan Tata Boga yang ideal ditempuh melalui elaborasi kurikulum ke dalam penerapan proses pengajaran yang mampu merangsang kreativitas siswa dalam mengolah makanan. Kemampuan siswa dalam mengolah makanan menjadi hidangan yang berkualitas adalah pencerminan prestasi siswa dalam mereduksi kemampuan yang diberikan oleh guru. Perwujudan prestasi siswa tertuang melalui kreativitas pengolahan makanan yang ditampilkan sebagai unjuk kerja yang dipresentasikan siswa.

Proporsi kemampuan siswa dalam meniru apa yang dibuat dan mendemonstrasikan apa yang telah dilakukan, serta mengembangkan materi baik secara teoritis maupun praktis menjadi ukuran kemampuan siswa ke dalam prestasi belajar, baik melalui dimensi intelektual, imajinatif, kreativitas, maupun keterampilan yang dimiliki secara maksimal.

Pencapaian kreativitas siswa dalam mengolah makanan sangat didukung oleh adanya sifat kreatif yang dimiliki siswa. Sifat kreatif ini sangat mendukung timbulnya perilaku kreatif. Secara teoretis perilaku kreatif ditentukan oleh tiga faktor. Sesuai dengan pendapat Treffinger (1980), tiga faktor yang menentukan perilaku kreatif, yaitu: (1) adanya motivasi, (2) kemampuan di atas rata-rata, dan (3) keterampilan.

Pendapat senada dikemukakan Arismunandar (1992), bahwa selain seseorang memiliki ciri-ciri berfikir kreatif, ciri-ciri lain yang berkaitan 
dengan perkembangan afektif seseorang sama pentingnya agar bakat kreatif dapat terwujud. Ciri-ciri afektif tersebut di antaranya: (1) ciri-ciri yang menyangkut sikap dan perasaan, (2) motivasi atau dorongan dari dalam untuk berbuat sesuatu, dan (3) pengabdian atau pengikatan diri terhadap suatu tugas.

Motivasi belajar sebagaimana dijelaskan Arismunandar merupakan salah satu faktor yang dapat memberikan kontribusi terhadap kreativitas. Motivasi belajar ini muncul karena adanya keingintahuan dalam mencoba menghasilkan sesuatu yang dianggap baru untuk memenuhi kepuasan dirinya.

Rasa keingintahuan ini juga dimiliki oleh siswa-siswa Sekolah Menengah Kejuruan (SMK) Jurusan Tata Boga. Rasa ini tentunya dapat mendukung terwujudnya sifat kreatif sehingga dapat mewujudkan kreativitas yang salah satunya adalah membuat kreasi dalam mengolah makanan. Pengetahuan gizi juga memberikan kontribusi terhadap kreativitas siswa dalam mengolah makanan. Pengetahuan gizi yang dimiliki siswa tampaknya menjadi prasyarat bagi siswa agar memiliki kemampuan untuk mengolah makanan secara kreatif.

Berdasarkan uraian di atas, maka penelitian ini mengkaji hubungan antara pengetahuan tentang gizi dan motivasi belajar, baik secara sendiri-sendiri maupun secara bersama-sama dengan kreativitas siswa dalam mengolah makanan. Penelitian ini dilakukan di Sekolah Menengah Kejuruan (SMK) Jurusan Tata Boga di Jakarta.

\section{TINJAUAN PUSTAKA}

Kreativitas seringkali dikaitkan dengan pribadi orang yang tidak seperti lazimnya, menentang arus, bandel, suka menciptakan hal-hal yang baru, serta menelorkan kreasi-kreasi baru. Arti kreativitas yang populer, penekanannya pada pembuatan sesuatu yang baru dan berbeda sehingga keunikannya merupakan prestasi yang sifatnya pribadi.

Kreativitas menurut Drevdahi (1990) merupakan kemampuan 
seseorang untuk menghasilkan komposisi, produk atau gagasan apa saja yang pada dasarnya baru dan sebelumnya tidak dikenal pembuatnya. Sementara Parker (1973), berpendapat bahwa kreativitas adalah sebagai seni untuk menemukan, mencoba, dan mengkombinasikan dari beberapa ilmu pengetahuan yang menghasilkan sesuatu yang baru.

Rhodes (1961) mengemukakan empat konsep yang terdapat dalam kreativitas, yakni orang, proses, tekanan, dan hasil. Orang menunjuk pada pribadi secara keseluruhan dalam kaitannya dengan lingkungan yang unik yang memberi peluang bagi pribadi untuk melaksanakan karya kreatif. Proses menunjuk pada proses penemuan karya kreatif yang diperoleh dari perwujudan dan respon dari aktivitas kesadaran dan ketidaksadaran pribadi. Tekanan menunjukkan pada suatu kondisi di mana individu dihadapkan pada lingkungan yang menantang sehingga mendorong individu untuk melakukan karya kreatif. Hasil menunjuk pada kemampuan untuk menghasilkan karya kreatif.

Kreativitas dalam mengolah makanan merupakan kemampuan membuat kombinasi-kombinasi baru dan memberikan gagasan baru yang diterapkan dalam pemecahan masalah sehingga memiliki pola pemikiran yang inovatif dalam mengolah makanan dengan memperhatikan tiga hal penting, yakni: (1) mata untuk menentukan segi keindahan, kebersihan, dan higienis, (2) hidung untuk menentukan segi aroma, dan (3) lidah untuk menentukan segi cita rasa makanan.

Kreativitas mengelola makanan menunjuk pada: (a) persiapan mengolah makanan yang menyangkut jenis makanan yang digunakan, kualitas bahan yang bernilai gizi, kesegaran bahan, perbandingan bahan, kebersihan dan kerapian, dan kesiapan bahan untuk diolah, (b) proses pengelolaan makanan yang menyangkut cara penyiapan alat untuk mengolah makanan, kebersihan, kerapian dalam pengolahan, cara pengolahan, dan ketepatan waktu pengolahan, dan (c) hasil pengolahan yang menyangkut keaslian hasil, keunikan, mengembangkan kreasi hasil menjadi sesuatu yang baru, kombinasi yang memenuhi syarat, adanya gagasan baru yang merupakan 
pengembangan syarat dasar, komposisi gizi, nilai gizi, dan cara menghidangkan.

Salah satu faktor yang mendukung kreativitas dalam mengolah makanan adalah pengetahuan tentang gizi. Pengetahuan adalah informasi yang dipadukan dalam struktur hubungan antara ide-ide.

Secara hierarkis dari tingkat yang paling spesifik sampai yang universal dan kompleks, aspek pengetahuan dapat dijabarkan dalam berbagai sub kategori, yakni: (1) pengetahuan spesifik, yang terdiri dari pengetahuan tentang terminologi dan pengetahuan tentang fakta-fakta spesifik, (2) pengetahuan yang menyangkut tentang cara-cara mempelajari fakta dan makna spesifik meliputi pengetahuan tentang konvensi atau kesepakatan, pengetahuan tentang kecenderungan dan urutan, pengetahuan tentang kriteria, dan pengetahuan tentang metodologi, serta (3) pengetahuan universal dan abstrak dalam suatu bidang, meliputi pengetahuan tentang prinsip dan generalisasi, serta pengetahuan tentang teori dan struktur (Bloom, 1981).

Pendapat lain dikemukakan Rich (1981), bahwa klasifikasi-klasifikasi dalam pengetahuan, salah satunya yang terkenal adalah Trichotomi Scheler, yakni: (1) pengetahuan instrumen; (2) pengetahuan intelektual, dan (3) pengetahuan spiritual. Sementara itu, Machlup menjelaskan bahwa klasifikasi pengetahuan dibedakan menjadi empat, yakni: (1) pengetahuan praktis, pengetahuan ini menambah pengetahuan para pekerja, pengambil keputusan, dan tingkah laku; (2) pengetahuan intelektual, pengetahuan ini memuaskan keingintahuan intelektual; (3) pengetahuan spiritual, pengetahuan ini dihubungkan dengan pengetahuan keagamaan tentang Tuhan dan cara untuk menyelamatkan jiwanya; dan (4) pengetahuan tambahan yang tak dinginkan, pengetahuan ini muncul di luar rasa ketertarikan, biasa didapatkan dengan sengaja, dengan tujuan menguasainya.

Menurut Direktorat gizi, ilmu gizi adalah ilmu yang mempelajari bagaimana cara memberikan makanan pada tubuh yang setepattepatnya sehingga tubuh dalam keadaan sehat yang optimal. IImu ini 
memberikan wawasan yang luas tentang hakekat gizi itu sendiri maupun istilah-istilah yang berkaitan dengan gizi serta cara memberikan makanan pada tubuh yang setepat-tepatnya.

Kemampuan yang merupakan refleksi dari penguasaan ilmu gizi dapat diamati melalui rujukan yang dikemukakan Gagne dan Briggs (1979), yakni: (1) keterampilan intelektual, (2) strategi kognitif, (3) informasi verbal, (4) keterampilan motorik, dan (5) sikap. Keterampilan intelektual adalah kesanggupan-kesanggupan yang dapat membuat individu memiliki kecakapan. Individu dapat juga membuat penyandraan, mengkonseptualisasikan segala sesuatu yang terdapat di lingkungannya.

Keterampilan intelektual ini meliputi: (1) kemampuan untuk membedakan benda yang tampak dari satu benda dengan benda yang lainnya. Kemampuan ini merupakan dasar dari keterampilan intelektual. Tanpa dimilikinya kemampuan membedakan, maka amatlah sulit untuk mempelajari konsep-konsep yang sifatnya kongkrit maupun yang abstrak, (2) kemampuan untuk membuat identifikasi atau penamaan terhadap objek-objek tertentu, (3) kemampuan untuk memberi arti bagi sesuatu hal, misalnya peristiwa, objek kelas, hubungan, dan lain sebagainya, (4) kemampuan untuk memberi interpretasi tertentu dan dalam situasi tertentu pula, (5) kemampuan untuk memecahkan masalah.

Strategi kognitif dalam teori belajar modern disebut proses kontrol. Peserta didik dalam proses internal telah memiliki kemampuan untuk menseleksi, atau dengan kata lain mampu mengarahkan perhatian, belajar, mengingat, dan berpikir. Strategi kognitif merupakan keterampilan mengorganisasikan diri secara internal sehingga mampu mengorganisasikan proses intelektual dalam kerangka belajar.

Keterampilan motorik merupakan keterampilan yang ditunjukkan melalui perilaku tertentu, misalnya mengendarai sepeda, menyetir, dan lain sebagainya. Sedangkan sikap yang merupakan ranah afektif dapat diamati melalui reaksi positif atau negatif terhadap seseorang, benda, atau situasi. 
Berg (1987) menjelaskan bahwa, adanya kekurangan gizi disebabkan kurangnya atau tidak adanya informasi yang memadai. Oleh sebab itu, kekurangan gizi dapat diatasi apabila tahu bagaimana seharusnya memanfaatkan segala sumber yang dimiliki. Selanjutnya dijelaskan bahwa pengetahuan gizi yang kurang akan berdampak bagi masalah ketidakseimbangan gizi.

Berdasarkan uraian tersebut, maka yang dimaksud dengan pengetahuan tentang gizi merupakan informasi tentang zat-zat makanan yang diperlukan oleh tubuh yang berasal dari makanan sehari-hari. Faktor lain yang mendukung kreativitas dalam mengolah makanan adalah motivasi belajar. Motivasi menurut Gage dan Berliner (1984) adalah istilah yang menggambarkan adanya kekuatan yang mendorong individu untuk melakukan kegiatan tertentu. Murray (1983), Atkinson dan Bancort (1974) menjelaskan bahwa penentu motivasi adalah kesimpulan perilaku, tujuan perilaku, dan peristiwa yang dapat merubah perilaku.

Terdapat dua hal penting dalam motivasi, yaitu (1) kemampuan untuk mencapai tujuan dan berusaha mengaplikasikannya; dan (2) hasil yang dicapai di dapat melalui rangkaian input dan output (Gagne, 1963). Selain itu, Stephen (1991) menjelaskan bahwa motivasi diartikan sebagai kemauan dalam diri, dalam usaha untuk mencapai tujuan yang lebih tinggi. Kondisi ini mendorong kemampuan seseorang dalam memuaskan kebutuhannya. Secara umum, motivasi diartikan sebagai usaha untuk memperoleh suatu tujuan yang terorganisir. Elemen dari motivasi di antaranya adalah usaha, tujuan yang terorganisir, dan kebutuhan.

Motivasi belajar adalah dorongan atau kekuatan yang menyebabkan siswa belajar. Ciri siswa yang memiliki motivasi belajar dapat diamati melalui intensitas belajarnya. Apakah siswa menggunakan waktunya pada pagi hari, siang hari, atau malam hari untuk belajar sesuai dengan waktu yang tersedia dan yang disengaja diadakan? Penggunaan waktu tersebut dilaksanakan secara kontinu dan konsisten. 
Ciri siswa yang memiliki motivasi belajar dapat diamati pula dari kesungguhan belajarnya yang dapat diamati dari indikator inisiatif belajar, keuletan, dan komitmen belajar. Karakteristik lain dari motivasi belajar adalah adanya upaya yang dilakukan untuk menguasai materi pelajaran. Cara menguasai materi pelajaran merupakan hal penting yang dimiliki siswa.

Pada dasarnya motivasi dapat dibedakan menjadi dua macam, yakni motivasi intrinsik dan motivasi ekstrinsik. Wankat dan Oreovick (2001) mengemukakan bahwa motivasi instrinsik bersifat internal yang biasanya menunjuk pada terpuaskannya kebutuhan dasar manusia. Motivasi ekstrinsik merupakan motivasi yang sifatnya eksternal dan termasuk banyak faktor yang menentukan, di antaranya hal-hal yang dilakukan guru, upaya-upaya yang dilakukan untuk meningkatkan semangat belajar, persahabatan, dan juga nilai yang diperoleh siswa.

Harter (1987) mengidentifikasi lima bagian penting tentang motivasi instrinsik yang dimiliki pelajar, di antaranya: (1) pilihan untuk menghadapi tantangan; (2) adanya keinginan untuk bekerja dalam upaya memuaskan minat dan keingintahuan; (3) mencoba menguasai materi pelajaran secara mandiri (memilih memecahkan masalah secara mandiri; (4) memiliki pendirian tentang apa yang harus dikerjakan di dalam kelas; dan (5) memiliki ukuran berhasil atas dasar penilaian pribadi.

Oxpord dan Shearin (2001) menganalisis 12 teori atau model motivasi. Selanjutnya dikemukakan bahwa konstruk motivasi sangat penting, namun konstruk motivasi tidak ditentukan oleh satu faktor melainkan oleh banyak faktor yang saling mempengaruhi. Faktor-faktor tersebut termasuk psikologi sosial, perkembangan kognitif, dan psikologi kebudayaan. Selanjutnya diidentifikasi 6 faktor yang mempengaruhi motivasi, yakni: (1) sikap, (2) kepercayaan diri, 3) tujuan, (4) keterlibatan, (5) dukungan lingkungan, dan (6) sifat pribadi.

Berdasarkan pembahasan di atas, yang dimaksud dengan motivasi 
belajar adalah dorongan atau kekuatan yang menyebabkan siswa belajar. Dorongan belajar dipengaruhi oleh faktor intrinsik dan faktor ekstrinsik.

\section{METODOLOGI}

Penelitian ini bertujuan untuk mengetahui hubungan antara pengetahuan tentang gizi dan motivasi belajar dengan kreativitas siswa dalam mengolah makanan. Penelitian ini dilakukan di di SMK Negeri Wilayah Jakarta Timur. Penelitian ini dilaksanakan pada Catur Wulan II Tahun Pelajaran 1999/2000, antara bulan Oktober 1999 sampai dengan Maret 2000.

Pengambilan sampel dilakukan dengan cluster random sampling. Pengambilan sampel dilakukan dengan memilih wilayah SMK Jakarta Timur, kemudian secara random memilih siswa kelas 2 SMK di Wilayah Jakarta Timur. Sampel dalam penelitian ini sebanyak 90 orang.

Metode yang digunakan dalam penelitian ini adalah metode survei dengan teknik korelasional. Metode ini memberikan deskripsi tentang variabel-variabel yang akan diteliti dan menyelidiki hubungan antar variabel. Teknik korelasional digunakan untuk mengetahui: (1) hubungan antara variabel pengetahuan gizi dengan kreativitas siswa dalam mengolah makanan, (2) hubungan antara variabel motivasi belajar siswa dengan kreativitas siswa dalam mengolah makanan, dan (3) hubungan antara variabel pengetahuan tentang gizi dengan kreativitas siswa dalam mengolah makanan.

Instrumen yang digunakan untuk menjaring data tentang pengetahuan mengenai gizi dan kreativitas siswa dalam mengolah makanan adalah tes. Sedangkan untuk menjaring data tentang motivasi belajar digunakan angket dengan skala Likert. Analisis yang dilakukan dalam penelitian ini terdiri dari analisis data dan analisis statistik. Analisis data dalam penelitian ini dilakukan dengan menggunakan statistik deskriptif. Analisis statistik dalam penelitian ini dilakukan untuk menguji hipotesis 
penelitian yang telah diajukan. Teknik analisis data meliputi uji persyaratan analisis data dan teknik pengujian hipotesis.

Sebelum melakukan pengujian hipotesis, maka dilakukan pengujian linearitas data dan keberartian regresi. Pengujian ini dimaksudkan untuk melihat apakah regresi yang diperoleh benar-benar berbentuk linear dan memiliki arti apabila digunakan untuk membuat kesimpulan mengenai hubungan di antara beberapa variabel yang sedang dianalisis. Pengujian hipotesis dalam penelitian ini menggunakan teknik analisis korelasi dan regresi. Hipotesis pertama dianalisis dengan menggunakan regresi linear. Apabila melalui analisis ini terbukti tidak linear, maka dilanjutkan dengan menggunakan regresi parabola (kuadratik).

Analisis hipotesis kedua menggunakan regresi dan korelasi sederhana. Analisis korelasi sederhana dilakukan dengan menggunakan rumus Pearson Product Moment dan diuji dengan menggunakan uji-t. Sedangkan hipotesis ketiga dianalisis dengan regresi dan korelasi ganda melalui uji-F.

\section{HASIL PENELITIAN DAN PEMBAHASAN}

Berdasarkan hasil analisis data dengan menggunakan teknik korelasional, diperoleh hasil yang menunjukkan bahwa pengetahuan gizi memiliki hubungan positif dan sangat signifikan dengan kreativitas siswa dalam mengolah makanan. Kadar hubungan antara pengetahuan tentang gizi dan kreativitas siswa dalam mengolah makanan ditunjukkan oleh koefisien korelasi $r_{y 1}=0,728$ sangat signifikan pada $\mu=0,01$. Koefisien determinasi yang diperoleh sebesar 0,530; dapat diinterpretasikan bahwa $53,0 \%$ variansi kreativitas siswa dalam mengolah makanan ditunjang oleh pengetahuan siswa tentang gizi. Keadaan seperti ini menunjukkan bahwa semakin baik pengetahuan tentang gizi yang dimiliki siswa maka semakin baik pula kreativitas siswa dalam mengolah makanan.

Hasil penelitian ini memberikan informasi bahwa, agar siswa mampu 
dan mempunyai kreativitas yang tinggi dalam mengolah makanan, maka siswa harus memiliki pengetahuan tentang gizi yang baik. Ini penting terutama bagi siswa-siswa yang menekuni tata boga (makanan). Mereka harus mampu mengenal secara detail mengenai jenis-jenis bahan dan makanan serta kandungan zat-zat yang dimilikinya. Dengan mengetahui kandungan zat yang ada pada makanan tersebut, diharapkan siswa akan mampu menemukan kreativitasnya dalam mengolah makanan sekaligus mampu menentukan bahwa makanan tersebut apakah mengandung kadar gizi yang tinggi.

Bila dikaitkan dengan hasil penelitian ini, jelaslah bahwa pola hidup yang sehat, salah satunya ditentukan oleh kadar makanan (dalam keluarga) yang dikomsumsi sehari-hari. Kadar makanan akan sesuai dikonsumsi sehari-hari apabila pegetahuan tentang gizi itu sendiri dipahami dengan baik.

Mengkonsumsi makanan yang memiliki kadar gizi tinggi perlu pula dilakukan siswa-siswa SMK Jurusan Tata Boga. Hal ini mengingat ketika ia merancang menu makanan kategori sehat, tentunya ia akan mempertimbangkan kandungan gizi yang ada pada makanan tersebut, seperti: kalori, lemak, protein, maupun vitamin-vitamin yang ada di dalamnya.

Hasil pengujian hipotesis kedua menunjukkan bahwa terdapat hubungan yang positif dan signifikan antara motivasi belajar dengan kreativitas siswa dalam mengolah makanan. Hubungan ini ditunjukkan oleh koefisien $r_{y 2}=0,863$ yang sangat signifikan pada $a=0,01$. Koefisien determinasi yang diperoleh sebesar 0,745, dapat diinterpretasikan bahwa $74,5 \%$ variansi kreativitas siswa dalam mengolah makanan ditunjang oleh motivasi belajar siswa. Keadaan seperti ini menunjukkan bahwa semakin kuat motivasi belajar siswa maka semakin tinggi pula kreativitas siswa dalam mengolah makanan. Hasil penelitian ini memberikan informasi bahwa, agar siswa mampu dan mempunyai kreativitas yang tinggi dalam mengolah makanan, maka siswa harus memiliki motivasi belajar yang kuat. 
Motivasi belajar yang kuat perlu dimiliki oleh siswa-siswa SMK juruan Tata Boga mengingat dengan adanya motivasi belajar berarti seseorang akan melakukan kegiatan belajar yang dilandasi oleh suatu kesadaran. Dengan memiliki motivasi belajar, maka siswa-siswa SMK jurusan tata boga akan lebih giat belajar dalam upaya-upaya yang dilakukan secara sungguh-sungguh untuk mempelajari ilmu gizi, hal-hal yang berkaitan dengan prosedur penyajian makanan yang mengandung gizi tinggi, praktek mengolah makanan bergizi secara mandiri, ketentuan berpraktek di laboratorium yang ada di sekolah, dan mencari informasi untuk memperkaya wawasan atau pengetahuan yang dapat dipraktekkan dalam praktek tata boga baik tingkat lokal, nasional, maupun tingkat internasional.

Motivasi belajar dalam mengolah makanan akan muncul karena adanya kebutuhan dalam mempelajari bagaimana mengolah makanan sesuai dengan apa yang diharapkan, baik sajian menunya, rasanya, maupun kandungan gizinya. Motivasi tersebut muncul karena ada kalanya bahan pangan tertentu dapat diolah menjadi bermacam-macam jenis makanan.

Hasil pengujian hipotesis ketiga membuktikan bahwa terdapat hubungan positif dan signifikan antara pengetahuan tentang gizi dan motivasi belajar secara bersama-sama dengan kreativitas siswa dalam mengolah makanan. Keeratan hubungan tersebut ditunjukkan dengan koefisien korelasi $R_{y 12}=0,971$ dan sangat signifikan pada $a=0,01$. Koefisien determinasi yang diperoleh sebesar $=0,942$ berarti $94,2 \%$ variansi yang terjadi pada kreativitas siswa dalam mengolah makanan dapat ditunjang oleh pengetahuan tentang gizi dan motivasi belajar siswa. Hasil pengujian ini memberikan informasi, bahwa untuk meningkatkan kreativitas siswa dalam mengolah makanan perlu meningkatkan pengetahuan mereka tentang gizi maupun motivasi belajar. Hal ini mengingat dengan dimilikinya pengetahuan tentang gizi dan motivasi belajar, maka siswa khususnya siswa-siswa SMK Jurusan Tata Boga akan terus berusaha untuk membuat kreasi-kreasi baru tentang pengolahan makanan yang tentunya memiliki kadar gizi tinggi. 
Diperolehnya koefisien determinasi sebesar 0,942 pada hasil pengujian hipotesis ini menunjukkan bahwa faktor pengetahuan gizi dan motivasi belajar memberikan kontribusi yang tinggi terhadap kreativitas siswa dalam mengolah makanan. Namun demikian masih terdapat sebesar $5,8 \%$ faktor lain selain faktor pengetahuan gizi dan motivasi belajar yang tidak terungkap dalam penelitian ini dapat menunjang terhadap peningkatan kreativitas siswa dalam mengolah makanan.

\section{KESIMPULAN}

1. Terdapat hubungan positif antara pengetahuan gizi dengan kreativitas siswa dalam mengolah makanan. Artinya semakin tinggi pengetahuan tentang gizi, maka semakin tinggi pula kreativitas siswa dalam mengolah makanan.

2. Terdapat hubungan positif antara motivasi belajar dengan kreativitas siswa dalam mengolah makanan. Artinya, semakin kuat motivasi belajar siswa, maka akan semakin tinggi pula kreativitas siswa dalam mengolah makanan.

3. Terdapat hubungan positif antara pengetahuan gizi dan motivasi belajar secara bersama-sama dengan kreativitas siswa dalam mengolah makanan.

\section{IMPLIKASI}

Berdasarkan kesimpulan hasil penelitian ini, maka perumusan implikasi menekankan pada upaya untuk meningkatkan pengetahuan gizi dan motivasi belajar siswa, sehingga kedua variabel tersebut dapat meningkatkan kreativitas siswa dalam mengolah makanan. Pertama, hasil penelitian ini mengungkapkan bahwa pengetahuan tentang gizi memiliki korelasi positif dengan dengan kreativitas siswa dalam mengolah makanan. Hal ini berarti bahwa pengetahuan gizi memberikan kontribusi terhadap kreativitas siswa dalam mengolah makanan. Karena itu, upaya untuk meningkatkan pengetahuan gizi siswa, juga merupakan upaya untuk meningkatkan kreativitas siswa dalam mengolah makanan. 
Untuk meningkatkan kreativitas siswa dalam mengolah makanan dapat dilakukan dengan upaya meningkatkan pengetahuan tentang gizi. Peningkatan pengetahuan tentang gizi dapat dilakukan melalui kegiatan:

1. Merumuskan program jangka panjang, berupa program yang dapat meningkatkan wawasan dan pengetahuan umum, yakni berupa perluasan wawasan pengetahuan tentang gizi, makanan yang sehat serta pola konsumsi hidup sehat. Artinya pengetahuan yang sangat penting bagi pemenuhan kebutuhan hidupnya. Tingkat pengetahuan gizi siswa ditingkatkan dalam rangka memperluas wawasan dan pengetahuannya tentang pola dan menu makanan sehat, khususnya makanan Indonesia.

2. Sebagai warga negara yang mempunyai kesempatan, kewajiban dan hak yang sama, lebih ditingkatkan perannya sehigga pemenuhan sandang, papan, dan pangan dapat dirasakan secara merata. Hal ini berdampak langsung pada kesiapan pemerintah dalam meletakkan strategi pembangunan yang bertujuan untuk mensejahterakan masyarakat secara adil dan makmur.

3. Upaya meningkatkan kualitas sumber daya manusia dan derajat kesehatan masyarakat dapat melalui berbagai media massa, media cetak dan media elektronik. Dalam rangka mensosialisasikan perilaku hidup sehat melalui konsumsi makanan sederhana, tetapi sehat dan bergizi perlu ditingkatkan lagi.

4. Upaya meningkatkan pengetahuan tentang gizi kepada masyarakat luas melalui program Posyandu dan melalui Puskesmas setempat agar pola konsumsi makanan sehat dapat diketahui secara jelas dan pasti. Hal ini sangat penting terutama untuk meningkatkan gizi BALITA secara umum agar tingkat kematian bayi dapat diminimalisasikan karena sejak awal bayi sudah dikenalkan dengan pola kebersihan dan hidup sehat, serta sejak dini bayi harus mengkonsumsi makanan-makanan sehat dan bergizi.

Kedua, hasil penelitian ini membuktikan bahwa motivasi belajar memiliki 
korelasi positif dengan kreativitas siswa dalam mengolah makanan. Hal ini berarti semakin kuat motivasi belajar siswa maka semakin tinggi kreativitas siswa dalam mengolah makanan. Hasil ini menunjukkan bahwa motivasi belajar turut memberikan konstribusi terhadap kreativitas siswa dalam mengolah makanan. Oleh karena itu, upaya meningkatkan motivasi belajar siswa juga merupakan upaya meningkatkan kreativitas siswa dalam mengolah makanan.

Untuk meningkatkan kreativitas siswa dalam mengolah makanan dapat dimulai dengan melakukan kegiatan yang dapat meningkatkan motivasi belajar, di antaranya:

1. Diperlukan program pendidikan lingkungan hidup bagi siswa Sekolah Menengah Kejuruan secara intensif, khususnya bagi siswa Jurusan Tata Boga, bahwa lingkungan sangat penting karena kebutuhan-kebutuhan primer, terutama pangan diperoleh dari sekitarnya.

2. Meningkatkan kualitas guru sebagai pangajar Tata Boga, agar lebih kreatif dalam menemukan dan membudidayakan potensi makanan asli Indonesia, sehingga ilmu tersebut dapat ditransformasikan kepada anak didik. Guru-guru yang mengajar di Jurusan Tata Boga, seyogyanya dikombinasikan dengan orang-orang profesional yang sudah malang melintang bekerja dalam bidang Tata Boga.

3. Pembenahan kurikulum di Sekolah Menengah Kejuruan (SMK) Jurusan Tata Boga perlu dilakukan agar siswa diberi peluang untuk melakukan praktek pengolahan makanan secara kontinyu dan berkesinambungan. Hal ini berkaitan dengan mata pelajaran memasak (mengolah makanan), yang seharusnya siswa diberi peluang untuk mengembangkan kreativitasnya dengan cara senantiasa sekolah menyediakan sarana dan prasarana yang dibutuhkan terutama bahan-bahan pangan yang siap diolah/ dimasak. Dengan demikian, siswa tidak bosan mendengarkan teori di kelas, namun siswa akan lebih inovatif dan kreatif dalam mengolah makanan. 
4. Meningkatkan motivasi belajar siswa dan praktek siswa dalam mengolah makanan, dengan cara produk makanan yang telah dihasilkan tersebut dapat disebarkan kemasyarakat sehingga ada timbal balik dan nilai tambah bagi sekolah dan siswa.

5. Upaya penyaluran lulusan SMK Jurusan Tata Boga ke lembaga terkait harus diprioritaskan seperti restoran, rumah makan, perusahaan nutrisi, dan hotel-hotel. Diharapkan upaya ini dapat memberikan motivasi untuk menemukan ide-ide baru yang berkaitan dengan pengolahan makanan.

6. Upaya meningkakan keterampilan dan kreativitas siswa SMK Jurusan Tata Boga dalam hal pengolahan makanan dengan cara mengirim mereka untuk mengikuti lomba merancang menu dan masakan.

Ketiga, hasil penelitian membuktikan bahwa pengetahuan gizi dan motivasi belajar secara bersama-sama memiliki korelasi positif dengan kreativitas siswa dalam mengolah makanan. Hal ini berarti pengetahuan tentang gizi dan motivasi belajar secara bersama-sama memberikan kontribusi terhadap kreativitas siswa dalam mengolah makanan.

Hasil penelitian menunjukkan bahwa kontribusi pengetahuan tentang gizi dan motivasi belajar terhadap kreativitas siswa dalam mengolah makanan sebesar 94,2\%. Hal ini menunjukkan bahwa $94,2 \%$ tercapainya kreativitas siswa dalam mengolah makanan didukung secara bersama-sama oleh pengetahuan tentang gizi dan motivasi belajar. Kontribusi yang diperoleh mengimplikasikan bahwa masih terdapat 5,8\% faktor lain yang dapat memberikan kontribusi terhadap kreativitas siswa dalam mengolah makanan. Implikasi ini berarti faktor yang dapat menunjang kreativitas siswa dalam mengolah makanan tidak hanya ditunjang oleh faktor pengetahuan tentang gizi dan motivasi belajar melainkan masih terdapat faktor-faktor lain yang juga memberikan kontribusi. Faktor lain yang tidak terungkap dalam penelitian ini, di antaranya kemampuan mengolah makanan, sikap siswa dalam mengolah makanan, sarana dan prasarana dalam 
mengolah makanan, dan lain sebagainya. Terungkapnya faktor-faktor lain yang dapat memberikan kontribusi terhadap kreativitas siswa dalam mengolah makanan selain pengetahuan tentang gizi dan motivasi belajar, memberikan peluang dilakukannya penelitian lanjutan.

\section{SARAN}

1. Perlu dilakukan pembenahan kurikulum Sekolah Menengah Kejuruan Jurusan Tata Boga berkaitan dengan komposisi yang ideal antara teori dengan praktek lapangan. Seharusnya Dinas Pendidikan, maupun Pusat Kurikulum dalam mengeluarkan kurikulum harus memberi porsi muatan lokal dan praktek yang memadai.

2. Penyebarluasan pengetahuan dan informasi berkaitan dengan kesehatan lingkungan, pola dan prilaku hidup sehat, serta pengenalan tentang makanan sehat yang bergizi, seharusnya dilakukan secara berkesinambungan. Sosialisasi itu sangat diperlukan dalam rangka menciptakan generasi dan sumber daya manusia yang sehat jasmani dan rohani.

3. Upaya untuk meningkatkan kreativitas siswa dalam mengolah makanan serta menggali potensi yang ada pada jenis makanan asli Indonesia, harus diimbangi dengan kesiapan pemerintah agar mampu menyalurkan lulusan Tata Boga untuk siap bersaing di pasar kerja, seperti: rumah makan, perusahaan nutrisi, restoran maupun hotel-hotel. Bila peluang ini tidak diperoleh, dikhawatirkan Jurusan Tata Boga dan sejenisnya di masa mendatang tidak akan diminati oleh generasi muda yang berniat mengembangkan potensi masakan asli Indonesia atau masakan internasional. Secara tidak langsung, pola konsumsi hidup sehat dan makan sehat sedikit demi sedikit akan terkikis dan ini sangat berbahaya bagi generasi mendatang. 


\section{DAFTAR PUSTAKA}

Anderson, Richard C. \& Rand J. Spiro, Schooling and The Acuisition of Knowledge (New Jersey: Lawrence Erlbaum Associates Publisher), 1977.

Atwater, Eastwood, Psychology of Teaching (New Jersey: Englewood Cliffs), 1983.

Beck, Mary E. Ilmu Gizi dan Diet. (Yogyakarta: Yayasan Essentia Medica), 2000.

Berg, Alan, Peranan Gizi Dalam Pembangunan Nasional (Jakarta: Rajawali Press), 1987.

Bloom, Benyamin S. Taxonomy of Educational Objectives, The Classification of Educational Goals, Handbook I: Cognitif Domain (New York: Longman Inc.), 1981.

Chisholm, Roderick M. Theory of Knowledge (New Jersey: Prentice Hall Inc.), 1989.

Cole, Peter G. \& Lorma KS. Chan, Teaching Principles and Practice (New York: Prentice Hall International, Inc.), 1987.

D.A. Booth, Psychology of Nutrition (New York: Taylor \& Francis), 1994.

Definitions of Creativity, 2001 (http://www.Ozemail. Com.An/-/Creative/ Basics/definitions, htm.)

Departemen Kesehatan RI. Buku Pedoman Teknis Penyediaan, Pengolahan, dan Penyaluran Makanan (Jakarta: Direktorat Jendral Pelayanan Medik), 1990.

Direktorat Gizi, Penuntun IImu Gizi Umum (Jakarta: Departemen Kesehatan RI), 1978.

Ebel, Robert L \& David A. Frisbie, Essentials of Educational Measurement (New York: Prentice Hall, Inc.), 1986.

Enhancing Student Motivation, 2001. (http://www.wpi.edu/ sig501/ motivation.html.)

Foster, John, Creativity and The Teacher (Glasgow: Macmillan Education Ltd.), 1971.

Gage \& Berliner, Educational Psychology. Third Edition (Boston: Hougton Mifflin Company), 1984.

Gagne, Robert M. Psychologycal Principles in System Development (USA: Rineart and Winston), 1963. 
Gandadipura, Mulyono, Kreativitas (Jakarta: Dian Rakyat), 1990.

Hersey, Paul \& Kenneth H. Blanchard, Management of Organizational

Behavior (New Jersey: Prentice Hall International, Inc.), 1991.

Hurlock, Elizabeth B. Perkembangan Anak, Jilid 2. Alih Bahasa:

Meitasari Tjandrasa (Jakarta: Erlangga), 1990.

Hutapea, Albert M. Menuju Gaya Hidup Sehat (Jakarta: PT Dian Rakyat), 1977.

Lefrancois, Guy R. Psychology for Teaching (USA: Wodsworth Inc.), 1985.

Klausemeier, Herbert J. Educational Psichology (New York: Harper \& Row Publisher), 1985.

Newman, Philip R. \& Barbara M. Newman, Living The Process of Adjusment (Ontario: The Dorsey Press Homewood), 1981.

Odum, Eugene P. Fundamentals of Ecology (London: WB. Saunders Company), 1997.

Oxford dan Sherian, Motivation and Transfer in Language Learning 2, 2001, (file:/A:Motivation and Transfer in Language Learning 2. htm.) Persagi, Komposisi Zat Gizi Pangan (Jakarta: Departemen Kesehatan RI), 1991.

Prasetya, Irawan, dkk. Teori Belajar, Motivasi, dan Keterampilan Mengajar (Jakarta: Depdikbud), 1994.

Rich, Robert E. The Knowledge Cyle (London: Sage Publication), 1981. Robbins, Stephen P. Organizational Behavior (New Jersey: Prentice Hall International, Inc.), 1991.

Soedarmo, Poerwo dan Sedioetomo A. Djaelani, IImu Gizi (Jakarta: PT. Dian Rakyat, 1977.

Suriasumantri, Jujun S. Filsafat IImu: Sebuah Pengantar (Jakarta: Pustaka Sinar Harapan), 1995.

Treffinger, Donald J. Encouraging Creative for Gifted and Talented (California: Ventura), 1980. 